\title{
INDICATORS OF NEUROMUSCULAR FATIGUE IN LEG PRESS EXERCISE IN MEN AND WOMEN
}

\author{
INDICADORES DE FADIGA NEUROMUSCULAR NO EXERCÍCIO LEG PRESS EM HOMENS E MULHERES
}

\begin{abstract}
Camila Brasileiro Azevedo Barros' 1 (ID (Physiotherapist)

Manoel da Cunha Costa ${ }^{2}$ D (Physical Education Professional) Antônio Gonçalves dos Santos (ID Neto' (Physical Education Student) José Hildemar Teles Gadelha' (ID (Physical Education Professional) Brendha Stephany Rodrigues da (iD Silva' (Physiotherapist)

André Luiz Demantova Gurjão' (ID (Physical Education Professional)

1. Universidade Federal do Vale do São Francisco, College of Physical Education, Petrolina, PE, Brazil. 2. Universidade de Pernambuco, Higher Education School of Physical Education, Recife, PE, Brazil.
\end{abstract}

\section{Correspondence:}

André Luiz Demantova Gurjão. Universidade Federal do Vale do São Francisco (UNIVASF), College of Physical Education (CEFIS). Av. José de Sá Maniçoba, S/N, Centro, Petrolina, PE, Brazil. 56304-917.

andre.gurjao@univasf.edu.br

\begin{abstract}
Introduction: Muscle fatigue is characterized by reduced ability to produce maximum strength or power, and may differ between men and women. Changes in velocity of movement during exercise, and in the ability to produce strength after exercise, may help when comparing fatigue in men and women. Objective: To analyze the differences between men and women in relation to number of repetitions, kinetics, kinematics and isometric force-time curve performance, and their respective muscle activation in horizontal leg press exercises. Methods: Fifteen men and fifteen women underwent isometric force-time curve (Cf-t) and electromyographic (EMG) assessments before and after performing horizontal leg press exercises. The exercises were performed in three sets until voluntary exhaustion, at $70 \%$ maximal repetition. During the exercises, kinetic and kinematic variables were obtained by means of two force transducers, a linear position potentiometer and accelerometer adapted for the horizontal leg press and synchronized by a signal conditioning plate. Results: The mean propulsive velocity significantly reduced between the first and last repetition of each series, with a similar reduction for men (-12.4 to $-29.2 \%)$ and women $(-29.2$ to $-35.6 \%)$. The same pattern was observed for the other kinetic and kinematic variables. The maximum voluntary contraction and peak force development rate also decreased for both men $(-15.1 \pm 8.7 \%$ and $-26.9 \pm 21.2 \%$, respectively) and women $(-13.9 \pm 10.4 \%$ and $-28.2 \pm 11.5 \%$, respectively). Conclusion: Based on the different variables used to quantify the effect of fatigue during and after horizontal leg press exercises, the research found practically no differences between men and women. Level of evidence Il; Comparative prospective study.
\end{abstract}

Keywords: Resistance training; Sex; Kinetics; Kinematics.

\section{RESUMO}

Introdução: A fadiga muscular é caracterizada pela redução na capacidade de produzir força ou potência máxima e pode diferir entre homens e mulheres. As alterações na velocidade de movimento durante o exercício e na capacidade de produzir força após o exercício podem auxiliar na comparação da fadiga em homens e mulheres. Objetivo: Analisar as diferenças entre homens e mulheres em relação ao número de repetições, cinética, cinemática e desempenho da curva força-tempo isométrica e sua respectiva ativação muscular no exercício leg press horizontal. Métodos: Quinze homens e 15 mulheres foram submetidos às avaliações da curva força-tempo (Cf-t) isométrica e atividade eletromiográfica (EMG) antes e após realizarem um exercício leg press horizontal. Os exercícios foram realizados em três séries a té a exaustão voluntária a 70\% de uma repetição máxima. Durante os exercícios, as variáveis cinéticas e cinemáticas foram obtidas através de dois transdutores de força, um potenciômetro linear de posição e um acelerômetro adaptados para o equipamento leg press horizontal e sincronizados por uma placa condicionadora de sinais. Resultados: A velocidade média propulsiva foi reduzida significativamente entre a primeira e a última repetição de cada série com uma redução similar em homens (-12,4 a-29,2\%) e mulheres (-29,2 a-35,6\%). O mesmo comportamento foi observado para as demais variáveis cinéticas e cinemáticas. A contração voluntária máxima e a taxa de desenvolvimento de força de pico foram reduzidas igualmente tanto para homens $(-15,1 \pm 8,7 \%$ e $-26,9 \pm$ $21,2 \%$, respectivamente) quanto para mulheres (-13,9 $\pm 10,4 \%$ e - $28,2 \pm 11,5 \%$, respectivamente). Conclusão: Com base nas diferentes variáveis utilizadas para quantificar o efeito da fadiga durante e após o exercício leg press horizontal, a pesquisa revelou que não há, praticamente, diferenças entre homens e mulheres. Nível de evidência Il; Estudo prospectivo comparativo.

Descritores: Treinamento de resistência; Sexo; Cinética; Cinemática.

\section{RESUMEN}

Introducción: La fatiga muscular se caracteriza por la reducción en la capacidad de producir fuerza o potencia máxima y puede diferir entre hombres y mujeres. Las alteraciones en la velocidad de movimiento durante el ejercicio y en la capacidad de producir fuerza después del ejercicio pueden ayudar en la comparación de la fatiga en hombres y mujeres. Objetivo: Analizar las diferencias entre hombres y mujeres con relación al número de repeticiones, cinética, cinemática y desempeño de la curva de fuerza-tiempo isométrica y su respectiva activación muscular en el ejercicio leg press horizontal. Métodos: Quince hombres y quince mujeres fueron sometidos a evaluaciones de curva fuerza-tiempo isométrica (Cf-t) y actividad electromiográfica (EMG) antes y después de 
realizar un ejercicio leg press horizontal. Los ejercicios fueron realizados en tres series hasta el agotamiento voluntario a $70 \%$ de una repetición máxima. Durante los ejercicios, las variables cinéticas y cinemáticas se obtuvieron mediante dos transductores de fuerza, un potenciómetro lineal de posición y un acelerómetro adaptados para el equipamiento leg press horizontal y sincronizados por una placa de acondicionamiento de señal. Resultados: La velocidad promedio propulsiva fue reducida significativamente entre la primera y la última repetición de cada serie con una reducción similar en hombres (-12,4a-29,2\%) y mujeres (-29,2 a-35,6\%). El mismo comportamiento fue observado para las demás variables cinéticas y cinemáticas. La contracción voluntaria máxima y la tasa de desarrollo de la fuerza de pico fueron reducidas igualmente tanto para hombres $(-15,1 \pm 8,7 \%$ y-26,9 $\pm 21,2 \%$, respectivamente) como para mujeres (-13.9 $\pm 10,4 \%$ y-28,2 $\pm 11,5 \%$, respectivamente). Conclusión: Con base en las diferentes variables utilizadas para cuantificar el efecto de la fatiga durante y después del ejercicio leg press horizontal, la investigación reveló que no hay, prácticamente, diferencias entre hombres y mujeres. Nivel de evidencia Il; Estudio prospectivo comparativo.

Descriptores: Entrenamiento de resistencia; Sexo; Cinética; Cinemática.

\section{INTRODUCTION}

Strength training (ST) has been recommended as a safe and effective method to improve musculoskeletal fitness in different populations. ' Adequate levels of maximum strength, power and local muscular endurance are positively associated with improved sports performance, functional independence and quality of life. ${ }^{1-3}$ The different metabolic, structural and functional adaptations of the neuromuscular system promoted by ST may be related to manipulation of the acute training variables (e.g., intensity and volume) and factors intrinsic to the subject (e.g., genetics and sex). Hunter ${ }^{4}$ suggests that men and women may have different adaptive responses to muscular fatigue, depending on the choice of the acute training variables (i.e., type and intensity of contraction, muscle group assessed and movement velocity).

Yoon et al. ${ }^{5}$ observed that women were less fatigued than men (17.0 min vs. 10.6 min, respectively) when they performed dynamic contractions of the elbow flexor muscles with slow velocity and low load (20\% of maximal voluntary contraction - MVC). No difference was found when intensity increased to $80 \%$ of CVM. On the other hand, Senefeld et al. ${ }^{6}$ did not show sex-related differences in the power decrease during the dynamic task under low load conditions (20\% of MVC), but with maximum movement velocity. Although these studies support the understanding of sex-related differences in the ability to resist fatigue in dynamic tasks, the intensities and durations of the tasks used are not in line with recommendations to promote increases in different expressions of muscle strength.1,2

When the objective is to promote increases in local muscular resistance of novice, it is recommended to perform moderate to high number of repetitions with a longer time under tension. ' Due to the inverse relationship between intensity and number of repetitions, lighter loads should be adopted to allow more repetitions. In addition, the increase in the time under tension can be obtained by intentional reduction of repetitions' cadence as a result of the change in muscular activation pattern.? Thus, when lighter loads and submaximal velocities are used, it is possible for women to be more resistant to fatigue compared to men in an exercise protocol characteristic of local muscular endurance. However, this is a hypothesis that needs to be investigated. The kinetics and kinematics changes induced by fatigue during multiple series until voluntary exhaustion and the pattern of isometric strength and muscle activation after exercise are important indicators of fatigue that can help in understanding the watery responses of men and women to the ST.

This study aimed to analyze the effect of sex-related differences in the number of repetitions, kinetics and kinematics during the three series until the voluntary exhaustion in the horizontal leg press exercise. In addition, the effect of exercise on the performance of the isometric force-time curve (Cf-t) and its respective muscle activation were analyzed.

\section{MATERIALS AND METHODS}

The sample consisted initially of 16 women and 15 men, who did not practice physical exercises. The following inclusion criteria were adopted: i) to be aged between 18 and 30 years; ii) not present any relative or absolute contraindications that make it impossible to carry out the proposed procedures; (iii) not performing strength training for at least three months. Only one participant was excluded from the study for not attending all evaluations. Thus, the study was conducted in 15 women and 15 men. All participants were informed of the procedures and signed an Informed Consent Term (Certificate of Presentation for Ethical Assessment-CAAE: 70529917.0.0000.5196).

Each participant attended the laboratory on four different occasions (48 to 72 hours apart). The aim of the first three visits were to familiarize with the isometric Cf-t record, determination of the absolute loads of $1 \mathrm{RM}$ and anthropometric assessment (first visit). The fourth visit was composed by: warm up; isometric Cf-t and electromyographic (EMG) activity of vastus lateralis (VL) and medial gastrocnemius (GM) of the dominant leg record; horizontal leg press exercise; isometric Cf-t and EMG activity record. All evaluations were performed on the same equipment and schedule. Participants were instructed not to engage in intense physical activity and avoid consuming alcohol and caffeine.

The absolute loads for 1RM were determined in a horizontal leg press (CyberTech, São José do Rio Preto, SP, Brazil) during the first three visits (48-72 hours of interval). Each participant was instructed to support the feet in the same position on metal plates that attach two force transducers (single point model, EMG System, São José dos Campos, SP, Brazil) to the horizontal leg press platform. The sliding seat was individually adjusted for the knee angle to start the effort by $90^{\circ}\left(0^{\circ}=\right.$ extended knees). The arms were positioned parallel to the trunk, with hands resting on the seat support. The Individual adjustment was noted and used in all study procedures (i.e., isometric assessment and dynamic exercise). The test procedures were based on Ribeiro et al.. ${ }^{8}$ After a warm-up with 15 repetitions at $50 \%$ of the estimated load for the first attempt, followed by a series of six repetitions at $70 \%$ was offered recovery interval of three minutes. The load was adjusted and participants were asked to perform two repetitions. If one or two repetitions were performed the load was increased by three to $10 \%$. In situations where the participant did not succeed in moving the load, decreases of three to 10\% were made. On each test day a maximum of five trials were performed. The highest load moved to one repetition was used for the analyzes. 
Familiarization with the evaluation procedures was carried out during the first three visits. On the fourth visit, after a dynamic warm-up $(1 \times 15$ repetitions at $40 \%$ of $1 \mathrm{RM}$ ), records of isometric (f-t and EMG activity of $\mathrm{VL}$ and GM muscles (dominant limb) were performed before and one minute after leg exercise horizontal press. Participants were instructed to reach their maximum strengths as fast as possible and sustain the effort for three seconds. Participants were verbally encouraged and visual feedback of strength performance was offered. During the evaluations that preceded the horizontal leg press exercise, five trials with a 3-minute recovery interval were recorded and the mean of the three best attempts was used for the analyzes. After the horizontal leg press exercise, only three trials were recorded, and the mean of the trials was adopted. ${ }^{9}$ The onset of force production was defined as the time instant at which the measured force value exceeded $4.5 \mathrm{~N}$ above the baseline. The peak force development rate (TDF) was determined by the first derivative test. The CVM was considered as the mean of $250 \mathrm{~ms}$ around the peak value of the force signal. The EMG activity of the $V L$ and $G M$ muscles were recorded synchronously with the isometric Cf-t, as recommended by Hermens et al. ${ }^{10}$ The raw signal of the EMG activity was initially rectified and the amplitude was determined by means of the root mean square (RMS) in the time window of the CVM.

The horizontal leg press exercise ( $3 \times 70 \%$ of 1 RM) was started three minutes after the initial isometric Cf-t records. Participants were instructed to perform repetitions until voluntary exhaustion in all three series, with full range of motion and cadence from one second to the concentric phase and one second to the eccentric phase (1:1), with no pauses between phases. A metronome set at 60 bpm was used to assist the participants. Kinetic and kinematic variables were obtained through force transducers, linear potentiometer and accelerometer. The linear potentiometer was used to determine the beginning and end of the concentric phase of each repetition. The accelerometer was used to subdivide the concentric phase in propulsive stage (acceleration $>0$ ) and braking (acceleration $<0$ ) and generate the absolute velocity curves (i.e., sum of the instant velocities). ${ }^{11,12}$ The mechanical power of the system was determined by multiplying the absolute velocity with the respective external force. ${ }^{12}$ The variables of the first repetition, of the repetition corresponding to half of the series and for the last repetition in the three series were used in the analyzes.

\section{Statistical analysis}

Statistical procedures were performed in SPSS software (version 22.0). The Shapiro-Wilk, independent Samples t test, two-way and three-way ANOVA for repeated measures and Bonferroni post hoc were used analyze the pattern of the different variables between men and women. The a-level of $5 \%$ was adopted.

\section{RESULTS}

Regarding the anthropometric characteristics, age and maximum strength, men presented higher values of height and 1RM when compared to women. (Table 1)

Table 1. Anthropometric characteristics, age and maximum strength (one maximal repetition test) in the horizontal leg press exercise for men and women.

\begin{tabular}{c|c|c}
\hline & Women $(\mathbf{n}=\mathbf{1 5})$ & Men $(\mathbf{n}=\mathbf{1 5})$ \\
\hline Age $(\mathrm{anos})$ & $24.3 \pm 3.3$ & $24.7 \pm 4.1$ \\
\hline Weight $(\mathrm{kg})$ & $62.8 \pm 18.8$ & $72.4 \pm 12.7$ \\
\hline Stature $(\mathrm{m})$ & $1.62 \pm 0.06$ & $1.74 \pm 0.08 *$ \\
\hline BMI $\left(\mathrm{kg} / \mathrm{m}^{2}\right)$ & $23.5 \pm 6.0$ & $24.0 \pm 4.2$ \\
\hline * Maximum strength $(\mathrm{kg})$ & $95.7 \pm 25.1$ & $166.3 \pm 54.8^{*}$ \\
\hline
\end{tabular}

The decrease in the number of repetitions between the series was similar between men and women (delta variation between the first and third series: $-39.5 \pm 19.1 \%$ and $-43.2 \pm 20.4 \%$, respectively) (Figure 1). Also, no differences were observed in the sum of the repetitions ( 46.3 \pm 10.7 vs. $45.9 \pm 13.9$ repetitions, respectively). Thus, the highest volume obtained by men $(5156.8 \pm 1329.6$ vs. $2952.4 \pm 930.7 \mathrm{~kg})$ is attributed to the higher absolute load lifted.

When compared to the initial repetition, mean propulsive velocity of the last repetition significantly reduced without differences between men (-12.4 to $-29.2 \%)$ and women (-29.2 to $-35.6 \%)$ (Figure 2). The same pattern was observed for the variables of mechanical power. (Table 2)

The magnitude of reduction after exercise for CVM and TDF peak was similar for women $(-13.9 \pm 10.4 \%$ and $-28.2 \pm 11.5 \%$, respectively) and men $(-15.1 \pm 8.7 \%$ and $-26.9 \pm 21.2 \%$, respectively). No change was observed for EMG activity. (Figure 3)

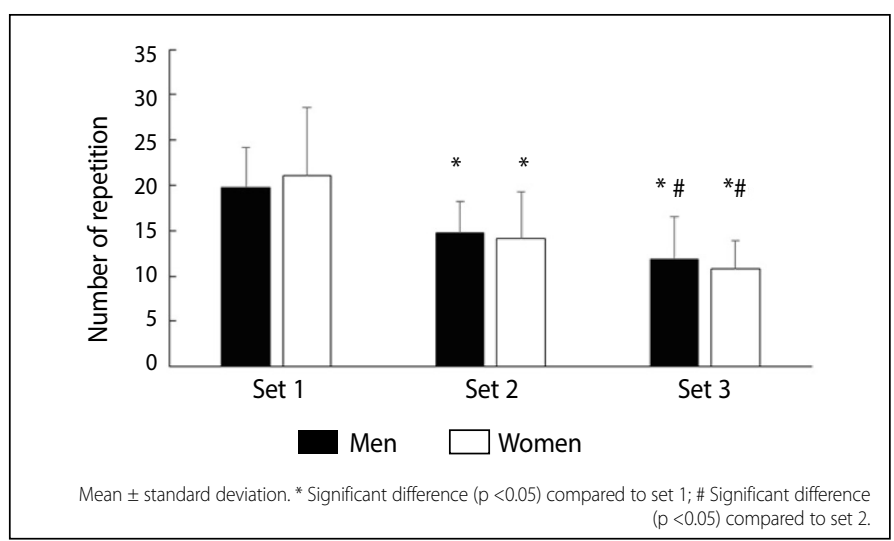

Figure 1. Number of repetitions performed per set until voluntary exhaustion for men $(n=15)$ and women $(n=15)$ in the horizontal leg press exercise.
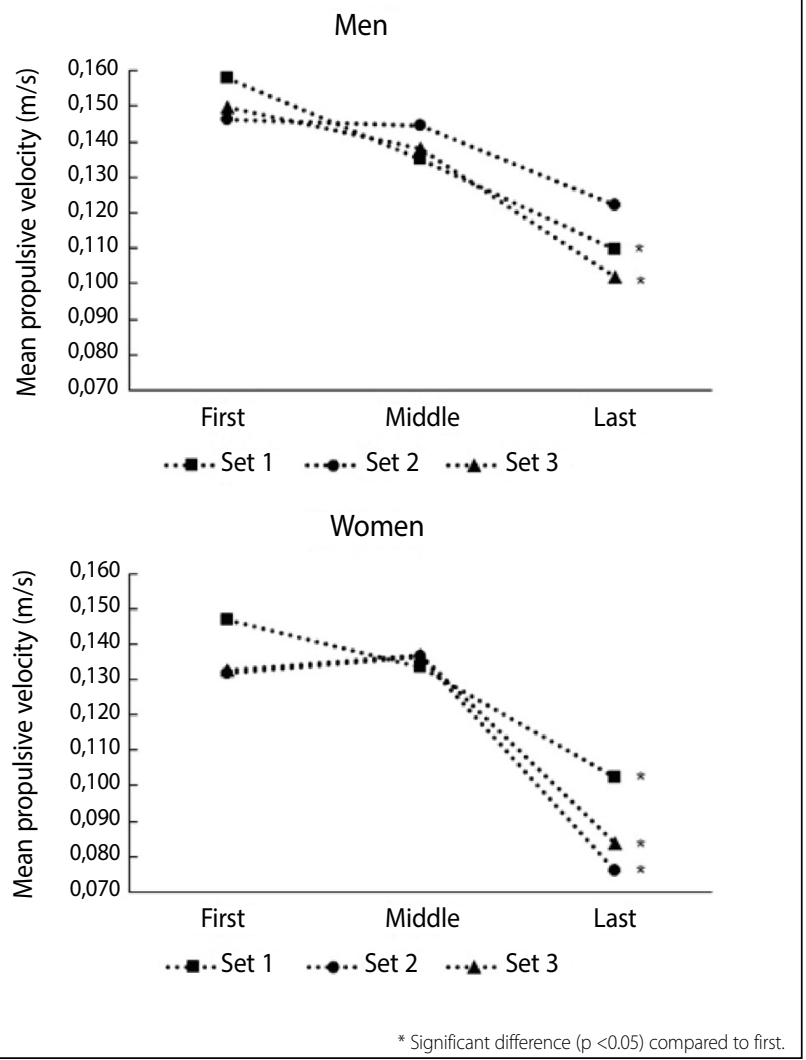

Figure 2. Mean propulsive velocity for the first repetition, repetition corresponding to half of the set (middle) and for the last repetition in the three sets performed by men $(n=15)$ and women $(n=15)$ in the horizontal leg press exercise. 
Table 2. Kinematic variables for the first repetition, repetition corresponding to half of the set (middle) and for the last repetition in the three sets performed by men (n $=15)$ and women $(n=15)$ in the horizontal leg press exercise.

\begin{tabular}{|c|c|c|c|c|c|}
\hline & & & $\begin{array}{c}\text { Mean } \\
\text { Power (W) }\end{array}$ & $\begin{array}{c}\text { Mean } \\
\text { Propulsive } \\
\text { Power (W) }\end{array}$ & $\begin{array}{c}\text { Peak } \\
\text { Power (W) }\end{array}$ \\
\hline \multirow{11}{*}{$\begin{array}{c}\text { Men } \\
(n=15)\end{array}$} & \multirow{3}{*}{ Set 1} & First & $312.3 \pm 94.7$ & $295.1 \pm 88.5$ & $503.9 \pm 14.2$ \\
\hline & & Middle & $253.3 \pm 11.8^{*}$ & $257.7 \pm 11.1$ & $457.8 \pm 21.4$ \\
\hline & & Last & $231.0 \pm 12.5^{*}$ & $213.4 \pm 11.2^{*}$ & $464.3 \pm 18.3$ \\
\hline & & $\begin{array}{c}\Delta(\%) \\
\text { First/Last }\end{array}$ & $-25.0 \pm 37.1$ & $-29.1 \pm 27.3$ & $-9.5 \pm 19.8$ \\
\hline & \multirow{3}{*}{ Set 2} & First & $268.8 \pm 11.5$ & $267.5 \pm 91.7$ & $434.3 \pm 16.7$ \\
\hline & & Middle & $265.9 \pm 12.9$ & $269.9 \pm 11.1$ & $477.2 \pm 20.6$ \\
\hline & & Last & $241.6 \pm 10.1$ & $227.6 \pm 89.6$ & $435.9 \pm 15.6$ \\
\hline & & $\begin{array}{c}\Delta(\%) \\
\text { First/Last }\end{array}$ & $-4.2 \pm 35.9$ & $-12.1 \pm 29.9$ & $7.2 \pm 39.3$ \\
\hline & \multirow{3}{*}{ Set 3} & First & $278.1 \pm 10.3$ & $269.3 \pm 93.7$ & $464.8 \pm 17.2$ \\
\hline & & Middle & $244.0 \pm 11.5$ & $244.4 \pm 87.2$ & $428.8 \pm 14.1$ \\
\hline & & Last & $196.6 \pm 11.0^{*}$ & $191.5 \pm 89.9^{*}$ & $401.2 \pm 19.5$ \\
\hline & & $\begin{array}{c}\Delta(\%) \\
\text { First/Last }\end{array}$ & $-23.1 \pm 48.6$ & $-24.2 \pm 40.0$ & $-10.6 \pm 44.2$ \\
\hline \multirow{11}{*}{$\begin{array}{l}\text { Women } \\
(n=15)\end{array}$} & \multirow{3}{*}{ Set 1} & First & $167.9 \pm 67.5^{\#}$ & $169.8 \pm 59.4^{\#}$ & $288.1 \pm 11.1^{\#}$ \\
\hline & & Middle & $154.9 \pm 71.1^{\#}$ & $154.4 \pm 58.6^{\#}$ & $288.3 \pm 13.0^{\#}$ \\
\hline & & Last & $118.3 \pm 52.8^{* \#}$ & $117.0 \pm 49.5^{* ~ \# ~}$ & $231.4 \pm 12.0^{\#}$ \\
\hline & & $\begin{array}{c}\Delta(\%) \\
\text { First/Last }\end{array}$ & $-25.5 \pm 30.7$ & $-30.1 \pm 25.1$ & $-15.3 \pm 39.9$ \\
\hline & \multirow{3}{*}{ Set 2} & First & $154.7 \pm 75.3^{\#}$ & $155.3 \pm 69.7^{\#}$ & $270.8 \pm 11.3^{\#}$ \\
\hline & & Middle & $159.7 \pm 66.2^{\#}$ & $158.7 \pm 53.6^{\#}$ & $293.4 \pm 11.0^{\#}$ \\
\hline & & Last & $100.2 \pm 61.2^{\#}$ & $100.8 \pm 54.8^{* \text { \# }}$ & $184.4 \pm 11.3^{\#}$ \\
\hline & & $\begin{array}{c}\Delta(\%) \\
\text { First/Last }\end{array}$ & $-30.2 \pm 92.2$ & $-36.2 \pm 65.0$ & $-27.5 \pm 54.4$ \\
\hline & \multirow{3}{*}{ Set 3} & First & $160.3 \pm 76.0^{\#}$ & $163.4 \pm 64.9^{\#}$ & $294.6 \pm 14.4^{\#}$ \\
\hline & & Middle & $168.0 \pm 73.9^{\#}$ & $168.0 \pm 61.9^{\#}$ & $302.0 \pm 12.1^{\#}$ \\
\hline & & Last & $97.0 \pm 47.1^{* \#}$ & $99.8 \pm 36.9^{* \#}$ & $207.4 \pm 96.7^{\#}$ \\
\hline & & $\begin{array}{c}\Delta(\%) \\
\text { First/Last }\end{array}$ & $-37.3 \pm 35.6$ & $-33.2 \pm 29.4$ & $-24.6 \pm 27.0$ \\
\hline
\end{tabular}

*Significant difference $(p<0.05)$ compared to the first repetition; \# Significant difference $(p<0.05)$ compared to men

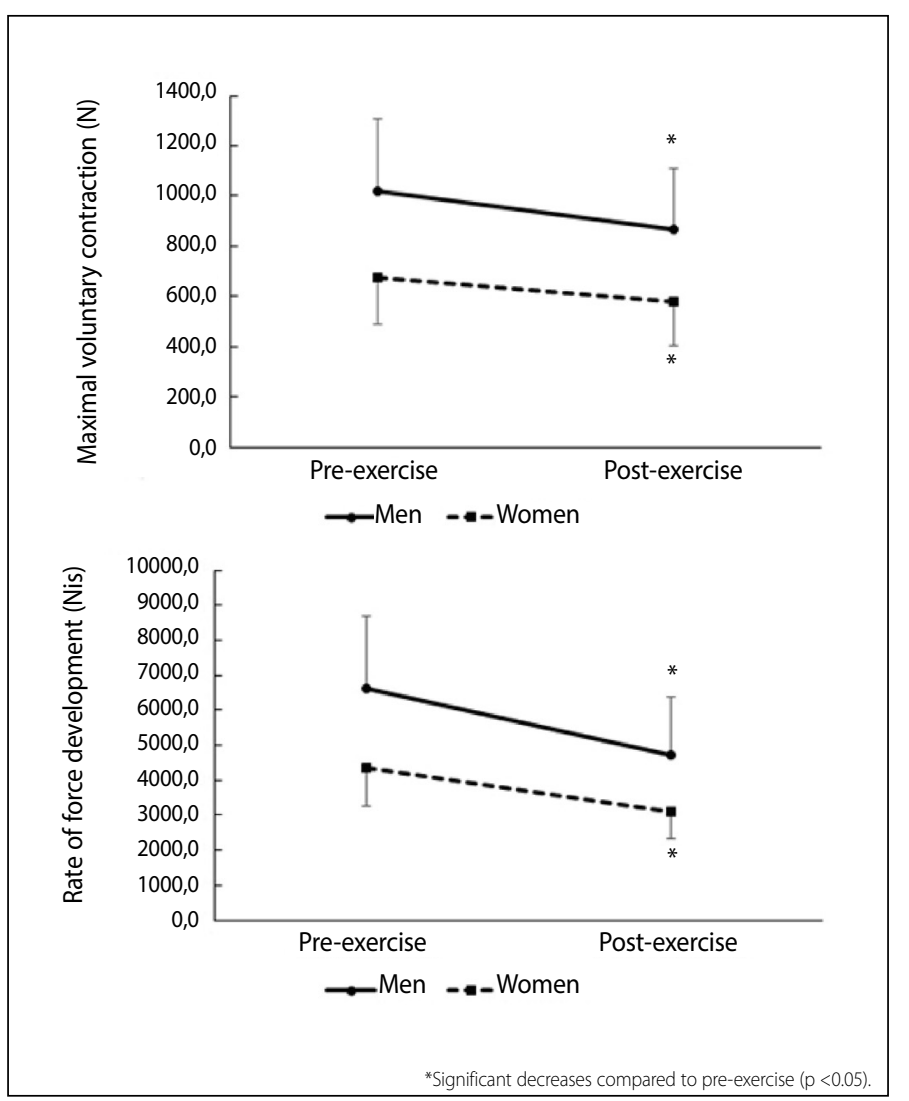

Figure 3. Pre and post-horizontal leg press exercise (70\% 1RM) isometric force-time curve for men $(n=15)$ and women $(n=15)$.

\section{DISCUSSION}

The main objective of this study was to analyze the effect of the sexual differences in the number of repetitions, kinetics and kinematics during the three series until the voluntary exhaustion in the horizontal leg press exercise. In addition, the pattern of isometric Cf-t and muscle activation before and after exercise was also investigated. These variables' analysis allowed us to quantify the extent of fatigue during (i.e., kinetics and kinematics) and after exercise (i.e., isometric Cf-t and EMG activity). As a main finding, fatigue-induced changes were similar between the sexes, with no changes in muscle activation.

The pattern of repetitions per set and total repetitions were not different between sexes. Our results are different from those reported by other studies ${ }^{13,14}$ Salvador et al. ${ }^{13}$ verified that women presented a performance of repetitions $24 \%$ lower than men.

For both sexes, both the mean propulsive velocity and the mechanical power variables presented decreases only for the last repetition, leading to an increase in the time of execution of the concentric phase. These results are in accordance with that reported by Gentil et al. ${ }^{15}$ when they observed a greater delta of variation between the penultimate and last repetitions (-22.1\%) in the mean propulsive velocity. Despite the higher mean propulsive power generated by men (Table 2), the mean propulsive velocity values were not different between the sexes (Figure 1), indicating that the greater mechanical power of men is related to the higher absolute load. Comfort et al., ${ }_{1}^{16}$ on the other hand, showed that men exhibited significantly $(p<0.05)$ higher bar velocity in the mid-thigh clean pull throw exercise. Differences in results may be associated with the control of the exercise cadence used in the present study and the type of exercise.

Gorostiaga et al. ${ }^{17}$ investigated the energy metabolism during repeated series in the horizontal leg press exercise $(5 \times 10$ RM). Linear negative correlation was observed between the mean change in power output of the last two repetitions (expressed as a percentage of the values of two first repetitions) and the decreases in ATP levels (expressed as a percentage of the initial value). In addition, the negative curvilinear correlation between the change in power output in the last two repetitions and the corresponding levels of muscle lactate indicates that the power output may change little if the lactate levels do not exceed a higher level of 10-15 $\mathrm{mmol} / \mathrm{kg}$ of wet muscle. However, when they exceed this higher level, the power output decreases drastically. In this study, the combination of performing repetitions with controlled velocity (1:1) and moderate loading (70\% of 1RM) allowed participants to achieve a large number of repetitions. Under these conditions, the rate of lactate production may not be high when compared to protocols involving maximal velocities or heavier loads, however, because of the longer time that exercise can be sustained, the maximum blood lactate concentration may be high, especially in final repetitions. ${ }^{18-20}$ In addition to the energy metabolism, the fatigue process can affect other components of the neuromuscular system and affect kinetics and kinematics of strength exercise, such as neurais changes (central and peripheral) or biomechanics of the muscle-tendon unit.

Previous studies have revealed a great variability in the magnitude of the acute decrease in fatigue-induced neuromuscular performance. Variables related to exercise (e.g., intensity and volume) or the sample investigated (e.g., gender, training level) may play a key role in the pattern of isometric strength after dynamic exercise. ${ }^{21}$ In addition, most investigations involving strength exercises with characteristics close to the present study (i.e., intensity, volume, and cadence) have been conducted in males and the direct comparison between males and females has received less attention. .1-24 $^{-24}$ Recently, Mendonca et al. ${ }^{25}$ submitted men and women to two protocols of elbow flexion exercises. The CVM of men and women showed similar relative decrease magnitude after both exercise protocols $(-37.2 \%$ and $-34.7 \%$, respectively). Although the magnitude of CVM reduction is greater than that found in the present study, the results agree with each other. 
The present study presents, as a limitation, the recording of performance variables (kinetics, kinematics, isometric (f-t and EMG activity) in the absence of control of the menstrual cycle phase of the participants, making it impossible to control possible changes that may occur in muscle strength in certain cycles. ${ }^{26}$

\section{CONCLUSION}

Based on the analyzes of the different variables that allowed quantification of the fatigue during and after exercise, it can be concluded that men and women were similarly influenced by the fatigue process.

\section{AGRADECIMENTOS}

Agradecemos a Fundação de Amparo à Ciência e Tecnologia do Estado de Pernambuco (FACEPE) pela bolsa de estudo.

All authors declare no potential conflict of interest related to this article

AUTHORS' CONTRIBUTIONS: Each author made significant individual contributions to this manuscript. CBAB and ALDG: responsible for elaborating the research project, processing the data, statistical analysis, description of the results, discussion and critical review; CBAB, AGSN and JHTG: performed the experimental procedures of data collection, contributed to the intellectual concept, discussion of the results and critical review; BSRS and MCC: contributed to the intellectual concept, discussion of the results, and the critical review. All the authors reviewed and approved the final version of the manuscript

\section{REFERENCES}

1. American College of Sports Medicine. American College of Sports Medicine position stand. Progression models in resistance training for healthy adults. Med Sci Sport Exerc. 2009;41(3):687-708.

2. Garber CE, Blissmer B, Deschenes MR, Franklin BA, Lamonte MJ, Lee IM, et al. American College of Sports Medicine position stand. Quantity and quality of exercise for developing and maintaining cardiorespiratory, musculoskeletal, and neuromotor fitness in apparently healthy adults: guidance for prescribing exercise. Med Sci Sports Exerc. 2011; 43(7):1334-59.

3. Resende Neto AG, Santos MS, Silva RJ, Santana JM, Silva-Grigoletto ME. Effects of different neuromuscular training protocols on the functional capacity of elderly women. Rev Bras Med do Esporte. 2018;24(2):140-4.

4. Hunter SK. Sex differences in fatigability of dynamic contractions. Exp Physiol. 2016;101(2):250-5.

5. Yoon T, Schlinder Delap B, Griffith EE, Hunter SK. Mechanisms of fatigue differ after low- and high-force fatiguing contractions in men and women. Muscle Nerve. 2007;36(4):515-24.

6. Senefeld J, Pereira HM, Elliott N, Yoon T, Hunter SK. Sex Differences in Mechanisms of Recovery after Isometric and Dynamic Fatiguing Tasks. Med Sci Sports Exerc. 2018;50(5):1070-83.

7. Sakamoto A, Sinclair PJ. Muscle activations under varying lifting speeds and intensities during bench press. Eur J Appl Physiol. 2012; 112(3):1015-25.

8. Ribeiro AS, Nascimento MA, Salvador EP, Gurjão AL, Avelar A, Ritti-Dias RM, et al. Reliability of one-repetition maximum test in untrained young adult men and women. Isokinet Exerc Sci. 2014; 22(3):175-82.

9. Maffiuletti NA, Aagaard P, Blazevich AJ, Folland J, Tillin N, Duchateau J. Rate of force development: physiological and methodological considerations. Eur J Appl Physiol. 2016;116(6):1091-116.

10. Hermens HJ, Freriks B, Disselhorst-Klug C, Rau G. Development of recommendations for SEMG sensors and sensor placement procedures. J Electromyogr Kinesiol. 2000;10(5):361-74.

11. Sanchez-Medina L, Perez CE, Gonzalez-Badillo JJ. Importance of the propulsive phase in strength assessment. Int J Sports Med. 2010; 31(2):123-9.

12. Thompson CJ, Bemben MG. Reliability and comparability of the accelerometer as a measure of muscular power. Med Sci Sports Exerc. 1999;31(6):897-902

13. Salvador EP, Dias RM, Gurjão AL, Avelar A, Pinto LG, Cyrino ES. Effect of eight weeks of strength training on fatigue resistance in men and women. Isokinet Exerc Sci. 2009;17(2):101-6.

14. Ratamess NA, Chiarello CM, Sacco AJ, Hoffman JR, Faigenbaum AD, Ross RE, et al. The effects of rest interval length manipulation of the first upper-body resistance exercise in sequence on acute performance of subsequent exercises in men and women. J strength Cond Res. 2012; 26(11):2929-38.

15. Gentil P, Marques VA, Neto JP, Santos AC, Steele J, Fisher J, et al. Using velocity loss for monitoring resistance training effort in a real-world setting. Appl Physiol Nutr Metab. 2018;43(8):833-7.

16. Comfort $P$, Jones PA, Udall R. The effect of load and sex on kinematic and kinetic variables during the mid-thigh clean pull. Sports Biomech. 2015;14(2):139-56.

17. Gorostiaga EM, Navarro-Amézqueta I, Calbet JA, Hellsten Y, Cusso R, Guerrero M, et al. Energy metabolism during repeated sets of leg press exercise leading to failure or not. PLoS One. 2012;7(7):e40621.

18. Siqueira LO, Prado MM, Simionato AR, Sancassani A, Pessôa Filho DM. Resposta aguda do lactato sanguíneo a diferentes protocolos de treinamento com pesos. Rev Bras Med Esporte. 2018;24(1):26-30.

19. Buitrago S, Wirtz N, Flenker U, Kleinöder H. Physiological and metabolic responses as function of the mechanical load in resistance exercise. Appl Physiol Nutr Metab. 2014;39(3):345-50.

20. Buitrago S, Wirtz N, Yue Z, Kleinöder H, Mester J. Mechanical load and physiological responses of four different resistance training methods in bench press exercise. J strength Cond Res. 2013;27(4):1091-100.

21. Conchola EC, Thiele RM, Palmer TB, Smith DB, Thompson BJ. Acute postexercise time course responses of hypertrophic vs. power-endurance squat exercise protocols on maximal and rapid torque of the knee extensors. J strength Cond Res. 2015;29(5):1285-94.

22. Häkkinen K. Neuromuscular fatigue in males and females during strenuous heavy resistance loading. Electromyogr Clin Neurophysiol. 1994;34(4):205-14.

23. Marshall PW, Robbins DA, Wrightson AW, Siegler JC. Acute neuromuscular and fatigue responses to the rest-pause method. J Sci Med Sport. 2012;15(2):153-8

24. Peltonen H, Walker S, Hackney AC, Avela J, Häkkinen K. Increased rate of force development during periodized maximum strength and power training is highly individual. Eur J Appl Physiol. 2018;118(5):1033-42.

25. Mendonca GV, Borges A, Teodósio C, Matos P, Correia J, Vila-Chã C, et al. Muscle fatigue in response to low-load blood flow-restricted elbow-flexion exercise: are there any sex differences? Eur J Appl Physiol. 2018;18(10):2089-96.

26. Pallavi LC, Souza UJ, Shivaprakash G. Assessment of musculoskeletal strength and levels of fatigue during different phases of menstrual cycle in young adults. J Clin Diagnostic Res. 2017;11(2):CC11-3. 